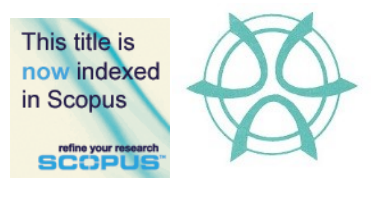

PLANNING MALAYSIA:

Journal of the Malaysian Institute of Planners

VOLUME 19 ISSUE 1 (2021), Page 114 - 126

\title{
AWARENESS OF COMMUNITY ON THE CONSERVATION OF HERITAGE BUILDINGS IN GEORGE TOWN, PENANG
}

\author{
Ummu Liyana Halim ${ }^{1} \&$ Noordeyana Tambi ${ }^{2}$ \\ ${ }_{1,2}$ Science Development, \\ Faculty of Social Science \& Humanities, \\ UNIVERSITI KEBANGSAAN MALAYSIA
}

\begin{abstract}
Having been gazetted as a World Heritage Site, George Town is known to have many heritage buildings that are more than a hundred years old. However, not all heritage buildings in George Town have appropriately been conserved by the local community, especially the owner and the tenant. This ignorance has caused severe issues of heritage buildings being neglected by the owner and the public. A stud has been carried out on the awareness of the local community in preserving historical buildings within George Town to gain insights into this issue. A quantitative method is used by distributing questionnaires to 387 respondents, which consists of the local community residing in George Town. The level of community awareness is measured to examine the extent of the local community being aware of the heritage buildings around them. Finding reveals that the community level of awareness to be moderate (mean=3.98), which reflects the ignorance of the local community in George Town towards preserving heritage buildings. Thus, the community in George Town is encouraged to be more vigilant in protecting the heritage buildings by joining activities related to heritage conservation held by the local authorities, NGOs, or even the local community. This activeness could ensure all the heritage buildings are protected from the effects of modernisation and be well-maintained for future use.
\end{abstract}

Keywords: Awareness, community development, participation, conservation, heritage

\footnotetext{
${ }^{2}$ Senior Lecturer at Faculty of Social Science and Humanities. Email: deyana@ukm.edu.my
} 


\section{INTRODUCTION}

The awareness of heritage conservation is increasing alongside the number of historical heritage sites being granted World Heritage Site status by UNESCO. The trend towards restoring, conserving, and adapting historic buildings and landmarks has also been discussed and practised extensively (Suraiyati, 2018). As a result, the heritage sites become unique tourist attractions, which will increase domestic income and promote economic growth (Boudiaf, 2017). For example, the inscription into the World Heritage Site (WHS) of Melaka and George Town in 2008 has given a new course to the tourism industry. The WHS status for George Town has caused tourism commodification on the heritage buildings, environment and economy within the surrounding area (Nurbaidura $\&$ Badaruddin, 2018). Apart from contributing to economic growth, the heritage tourism industry has also positively impacted employment opportunities.

However, as time passed, the quality of monuments and historic buildings in George Town has declined, with signs of neglect. This negligence is due to the lack of community participation in conserving the heritage buildings. Some of these heritage buildings have been badly damaged due to natural causes and in need of restoration (Sinar Harian, 2020; Sofia, 2016; Ghafar, 2009). This situation would be worsened when the owners demolish the historic buildings due to ignorance of the historical value and prioritisation to modernise and develop alongside globalisation. One of these demolished heritage buildings demolished is the Runnymede Hotel that was built in 1920 with more than 200 years of history. The building is considered one of the famous historical buildings in George Town as once inhabited by Sir Stamford Raffles when he was the Assistant Secretary to the Governor of Penang Island. The Runnymede Hotel building was also used as a British military hospital during World War Two.

Some of the owners who have inherited the heritage buildings have sold the buildings to investors to be used as commercial units (Yusri, 2017; Sofia, 2016). Some of these buildings are located at Lebuh King and Lebuh Church. Based on data by the Penang Heritage Trust (PHT), a total of 24 units of heritage buildings located within the World Heritage Site Zone have already been sold to foreigners. Many historic buildings have not been preserved in the right way, with some examples of these buildings being the Penang City Hall and some located at Padang Kota Lama (Balvin, 2019).

The Penang state government has given the 'green light' to the demolishing of a 100-year-old bungalow at Peel Highway to make way for Medical City (Dermawan, 2018). However, several NGOs and heritage activists have opposed demolishing these heritage bungalows and believe that the state government is not serious about protecting heritage buildings. The demolition of heritage buildings is also contrary to the National Heritage Act (2005), which states that heritage buildings over 100 years are prohibited from being demolished and should be conserved as national heritage. The government's 
Ummu Liyana \& Noordeyana

Awareness of Community on The Conservation of Heritage Buildings In George Town, Penang

decisions to demolish heritage buildings have set an appalling example to the community, which could have led to the negligence of heritage issues that occur in their areas. For example, a study by Castro, Guccio, and Rizzo (2011) states that low levels of awareness on heritage sites contribute to ignorance of heritage sites, which can cause the community to refuse any engagement or join heritage conservation activities. Failure of heritage awareness will lead to difficulties in preserving heritage assets, especially heritage buildings (Jaki, 2014; Amer et al., 2011). Nonetheless, the community bears the same responsibilities as the government in the conservation and preservation of heritage buildings (Jaki, 2014). Many heritage buildings belong to individuals than to the government. Hence, individuals in society should be dedicated and concerned about maintaining heritage buildings preservation and be responsible for the heritage buildings. Therefore, this article focuses on the level of awareness among the local community towards heritage conservation in George Town, Penang.

\section{LITERATURE REVIEW}

\section{Heritage conservation}

Heritage was a cultural process that described the history of a community, city, or area inherited by a community group to another community (Azizan et al., 2020; Wang, 2020; Awad \& Bleibleh 2020). Heritage should not be considered an objective that had to be taken care of individually but should be the foundation of community development, with shared values among the community members (Waterton \& Watson 2015). The term heritage can also be used in various contexts, such as non-physical elements of history, which included culture and art and past artefacts or relics without permanent physical structure connected to past events (Tunbridge \& Ashworth, 1996). Heritage can also be defined as any hereditary relic, whether artificial or natural, movable or immovable, and visible or invisible, that symbolised the life and identity of (Akta Benda Purba, 1976).

Heritage conservation was also used to describe the preservation of architectural monuments or historical places using methods and materials close to the original building during reconstruction (Asyaari, 2018; Hamsah, 2006). These physical conservations focused on preserving and caring for heritage buildings from destruction by considering the importance of society and country (Azizan et al., 2020; Johar et al., 2011). The term can also be interpreted as all the processes involved in taking care of a particular place to preserve the importance of heritage and protect the value of cultural heritage from being damaged or lost (Esther et al., 2016).

The history of heritage conservation in Malaysia began only recently, around the 1960s to the 1980s, when the economy was developing. Bujang Valley in Kedah and other major towns, such as Kuala Lumpur and Georgetown, had been among the first locations to have heritage buildings conserved in Malaysia. Social agencies, such as the Malaysian Heritage Body, established since 1983, 
had also created awareness of the importance of historical architecture. Nonetheless, the conservation of cultural heritage in Malaysia had improved after George Town and Melaka were recognised as World Heritage Sites by UNESCO on 7 July 2008 in Quebec, Canada (Ghafar, 2010).

Heritage conservation was fundamental in renovating old cities, such as Georgetown and Melaka, as UNESCO World Heritage Sites. Specifically, conservation of heritage buildings must be prioritised to prevent the country from losing its heritage, which was a shared responsibility by all society levels and not limited to professionals (Awad \& Bleibleh, 2020; Normah et al., 2018). Authorities, such as the Ministry of Culture, the National Museum and the Department of National Heritage, played an essential role in supporting and encouraging communities and relevant people to contribute to the conservation of heritage buildings. Aside from making the heritage buildings liveable, effective conservation works could also help maintain the uniqueness of heritage buildings as time passes (Azmin et al., 2017).

\section{Local communities' awareness}

Generally, awareness can be defined as a condition or ability to view, feel, or realise an event that had occurred (Hafsah et al. 2019; Nur Zalina et al., 2020). This historical awareness was also vital to create a dependency between individuals and society and between society and the environment (Hargreaves \& Fink 2004). Aisiah et al. (2016) defined historical awareness as a state and thought process that occurred when individuals remember the meaning and purpose of history. Moreover, another essential aspect of historical awareness was understanding historical events in the form of values, effects, and experiences gained from past events. Historical awareness was important for every individual in the country as individuals who did not understand and had no historical heritage awareness may lose their identity (Yung et al., 2011).

The awareness of the local community in George Town towards heritage buildings conservation was measured using the model of heritage awareness was adapted by Aisiah et al. (2016). The level of heritage awareness in the George Town community was considered high if all four components were prevalent. On the other hand, any one of the absent components would mean that the level of community heritage awareness was low and should be improved (Aisiah et al., 2016). Hence, all four of these components played a crucial role in assessing the degree of understanding of heritage among the local community. 
Ummu Liyana \& Noordeyana

Awareness of Community on The Conservation of Heritage Buildings In George Town, Penang

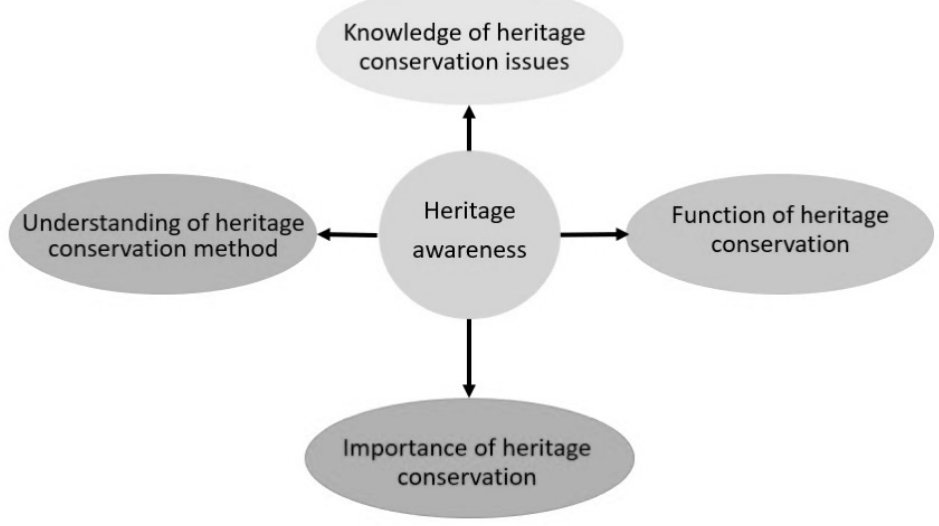

Figure 1: Heritage awareness model Source: modified from Aisiah et al. (2016)

\section{METHODOLOGY}

This study had employed a quantitative approach by using a questionnaire as the main instrument to obtain data. The questionnaires were distributed to 387 respondents online, with some at the George Town conservation zone through convenience sampling. The items used in the questionnaire consisted of two parts, which was Part A, which focused on the background of the respondents and Part $\mathrm{B}$, which was related to the level of community awareness in heritage building conservation. All questionnaire items developed formed a construct representing the real situation that effectively measured the awareness level of the local community.

\section{FINDING}

\section{Background of the Community}

Results for this study on the conservation zone of George Town were based on 387 responses received from respondents who worked, studied, or lived within the area of George Town. The study recorded that the Malays were the majority of people who participated in the study, followed by the Chinese and Indians. There are also races from other categories, such as Sabahans and Sarawakians residing in George Town and the Indian-Muslims living and working in George Town.

In terms of age, most respondents were youths between the ages of 20 to 30. As for education level, many respondents had at least an SPM, Diploma, Bachelor or Master's certification. This result indicated that the current generation had obtained formal education within Malaysia, with at least, the Sijil Pelajaran Malaysia certificate. The percentage of respondents with Penilaian Menengah 
Rendah (PMR) and Sijil Rendah Pelajaran (SRP) education was small at 1.6\%, while $0.3 \%$ of the respondents only had primary school education.

\begin{abstract}
Assessing the awareness level of the local community in George Town
Overall, the analysis and discussion conducted in this study found that the level of community awareness was moderately high. The level of community awareness in the conservation of heritage buildings was measured using the heritage awareness model with four elements: awareness of heritage issues, awareness of heritage methods, awareness of the function of heritage, and awareness of the importance of heritage. Based on these four elements, the awareness towards heritage issues was the most prominent, with the highest cumulative mean value $($ mean $=4.10)$. These results suggested that most communities were already aware that George Town had been gazetted as a World Heritage Site. The local community was also aware of the status awarded to George Town and realised that the residence area had high-value heritage buildings.
\end{abstract}

Table 1:Awareness in conservation issues of heritage buildings

\begin{tabular}{lcc}
\hline Items & Mean & $\begin{array}{c}\text { Standard } \\
\text { Deviation }\end{array}$ \\
\hline Heritage buildings bear great heritage values & 4.71 & 0.626 \\
Must be conserved by local government & 4.5 & 0.859 \\
Must be restored for continuous use & 4.29 & 0.943 \\
Must be conserved by the buildings' owners & 4.05 & 1.071 \\
George Town had been gazetted as World Heritage & 4.03 & 1.194 \\
Sites & 3.85 & 1.292 \\
Heritage buildings are neglected and obsolete & 3.84 & 1.444 \\
Many heritage buildings had been sold to developers & & 1.469 \\
Issues related to heritage buildings conservation is & 3.56 & \\
unimportant & & \\
\hline
\end{tabular}

Besides, the local community was also aware of the need for heritage buildings to undergo renovations for continuous use. This result indicated that the local community was aware of conservation procedures and issues towards the heritage buildings in George Town (Table 2). Nonetheless, the local community was found to have disagreed that many of the heritage buildings in George Town were dilapidated and neglected. This finding further indicated that the conservation of heritage buildings in George Town could prevent the area from a neglected appearance. Besides, the local community agreed that heritage buildings should be preserved to be used continuously in terms of quality. Maintaining heritage buildings was a shared responsibility of both the local government and community, especially among the owners and tenants of these 
Ummu Liyana \& Noordeyana

Awareness of Community on The Conservation of Heritage Buildings In George Town, Penang

heritage buildings. Adequate policies focused on implementation, adaptation, and mitigation strategies (Sesana et al. 2020) are also necessary to manage cultural heritage at risk.

Table 2:Awareness in methods of conservation for heritage buildings

\begin{tabular}{lcc}
\hline Item & Mean & $\begin{array}{c}\text { Standard } \\
\text { Deviation }\end{array}$ \\
\hline $\begin{array}{l}\text { Local government and NGO should provide funds for } \\
\text { conservation works }\end{array}$ & 4.3 & 0.959 \\
$\begin{array}{l}\text { Renovation is one of the methods in heritage } \\
\text { conservation }\end{array}$ & 3.94 & 1.283 \\
$\begin{array}{l}\text { Reconstruction is one of the methods in heritage } \\
\text { conservation }\end{array}$ & 3.79 & 1.244 \\
$\begin{array}{l}\text { Restoration is one of the methods in heritage } \\
\text { conservation }\end{array}$ & 3.89 & 1.331 \\
$\begin{array}{l}\text { Conservation works are not done in a proper and } \\
\text { planned method }\end{array}$ & 3.82 & 1.352 \\
$\begin{array}{l}\text { Tourism tax should be raised to provide funds for } \\
\text { conservation works }\end{array}$ & 3.77 & 1.438 \\
$\begin{array}{l}\text { Limited funds caused conservation works to halt } \\
\text { All changes related to heritage building need to be } \\
\text { approved by the local community }\end{array}$ & 3.43 & 1.380 \\
\hline
\end{tabular}

The understanding of conservation methods among the community was less encouraging. The result indicated that there were still members of the community who did not know that restoration, reconstruction, and renovation are among the methods used to preserve heritage buildings (Table 3 ). The average mean value for community understanding was 3.78 , which was the lowest compared to the other elements in heritage awareness. Nonetheless, this result should not indicate that the community was to be blamed on the insufficient understanding of conservation methods among the community as these members may not have been exposed to heritage conservation processes. Many community members had also stated that they used to be involved in activities related to heritage building conservation but were unfamiliar with the specific terms used due to the lack of formal training and information related to conservation.

Local communities who were exposed to conservation methods and work would more likely participate in heritage conservation works. A respondent from Balik Pulau Polytechnic had stated that he did not know about the method used in the conservation of heritage buildings because he was unaware of the methods used for conservation of the heritage buildings due to lack of exposure. Thus, there was a high possibility for him to be involved in conservation activities if the information was made known. This finding further supported Solihah et al. (2015), who argued that communities who lack information and knowledge about 
heritage conservation would have a high tendency not to be involved in heritage conservation efforts.

Besides, the local community had also agreed that the government and NGOs should provide funds and assistance to conserve heritage buildings, especially for owners and tenants of these heritage premises. As previously discussed, limited financial support was a factor for failure in the conservation of heritage buildings with the proper methods. Thus, with stable financial assistance, heritage building conservation works could be carried out correctly. Asyaari (2018) argued that archaeology and conservation were essential in creating, preserving, and protecting national heritage. As a result, authorities such as the Malaysian Department of Culture, Art and Heritage and related organisations (including the Department of the Museum and the Department of Heritage) were developed to protect and enhance national heritage.

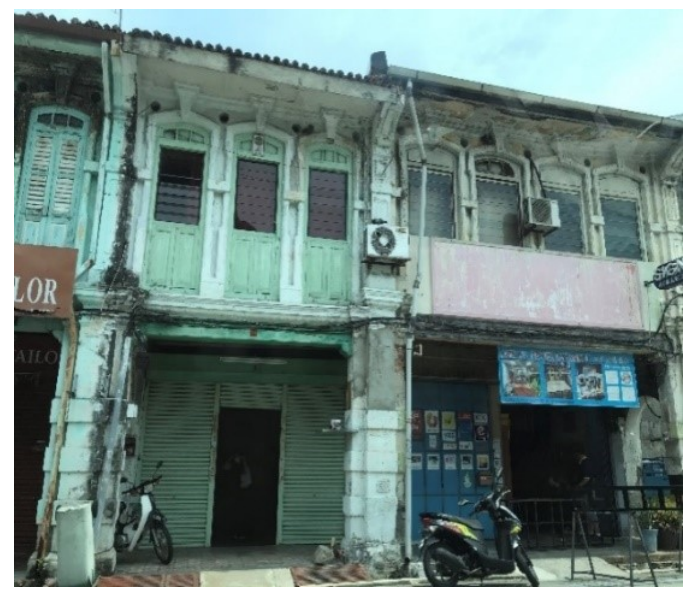

Figure 1: Heritage building that had undergone renovation

Conservation work on the heritage buildings in George Town could be carried out with proper planning by adhering to the appropriate conservation methods. For example, most of the conservation work on the heritage buildings in George Town was part of local government projects, such as the George Town Fire Station project, which was over 100 years old, and the Sia Boey conservation project. The operation of these projects was also managed by individuals with experts in the field of conservation. However, for privately owned heritage buildings, owners or tenants of these heritage premises preferred to repair damage to buildings without hiring individuals who specialised in heritage conservation. As a result, many privately owned historical buildings lost heritage features. Besides reducing the aesthetic value of the buildings, the historical value was diminished as well. This situation indicated that the local community must be 
Ummu Liyana \& Noordeyana

Awareness of Community on The Conservation of Heritage Buildings In George Town, Penang

well aware of the proper conservation methods to ensure that the heritage buildings can be well preserved to maintain the aesthetic essence of the buildings.

Table 3:Awareness in the function of heritage buildings conservation

\begin{tabular}{lcc}
\hline Item & Mean & $\begin{array}{c}\text { Standard } \\
\text { Deviation }\end{array}$ \\
\hline Improve the surrounding area & 4.4 & 0.892 \\
Heritage conservation is just wasting money & 4.33 & 0.989 \\
Helps in promoting George Town as WHS & 4.31 & 0.903 \\
Prevent the area from being neglected & 4.08 & 0.991 \\
Cause property values in surrounding areas to increase & 4.05 & 1.089 \\
Improve the cleanliness of the area & 4.03 & 1.186 \\
Improve the quality of amenities in the area (e.g.: road & 3.62 & 1.476 \\
network). & 3.46 & 1.529 \\
Prevent the opening of new areas & & \\
\hline
\end{tabular}

Meanwhile, community awareness in the function or purpose of conservation was reasonable with a mean value $=4.04$. This result indicated that the community knew and understood the role of heritage buildings in George Town. Most of the heritage buildings in George Town were shophouses. The conservation of these buildings can save financial resources from purchasing new land for business purposes through the adaptive reuse process. This process allowed optimal use of possible space available, including marginal areas, to fulfil the desired economic goals re-purpose the buildings and spaces (Haroun et al. 2019). Furthermore, George Town had a high population density to sustain the economic supply. Besides, well-preserved heritage buildings could also enhance the image of the surrounding area, which would further highlight the identity of George Town as a World Heritage Site.

Table 4: Awareness in the importance of conservation of heritage buildings

\begin{tabular}{lcc}
\hline Item & Mean & $\begin{array}{c}\text { Standard } \\
\text { deviation }\end{array}$ \\
\hline A symbol of pride for the local community & 4.42 & 0.858 \\
Ability to attracts tourists & 4.26 & 0.990 \\
As a place for the community's interaction & 4.11 & 1.112 \\
Unique architecture & 4.09 & 1.137 \\
Portrays local's culture & 3.86 & 1.364 \\
Portrays the life of the previous community & 3.76 & 1.307 \\
Can be makes gallery, souvenirs shop, hotel and & 3.54 & 1.356 \\
restaurant & & \\
\hline
\end{tabular}


The local community in George Town also recognised the value of restoration of historic buildings (Table 5). The mean value for this element was 4.0. Many organisations had acknowledged that heritage buildings in George Town must be preserved because of the unique designs that symbolised the local culture. Hence, the heritage buildings in George Town are often used as souvenir shops, hotels, and even restaurants. The local community also made these heritage buildings a place for social interaction, such as cultural associations. This finding indicated that the community knew and understood that heritage conservation was vital for the future generation. Furthermore, preserving heritage buildings also helped current generations to appreciate history and embrace the constant changes in society. Nonetheless, the rapidly changing world was considered an aspect of stability (Awad \& Bleibleh, 2020).

Table 5: Cumulative mean for components in community awareness

\begin{tabular}{lcc}
\hline Components & Cumulative mean & $\begin{array}{c}\text { Standard } \\
\text { Deviation }\end{array}$ \\
\hline $\begin{array}{l}\text { Issues of heritage } \\
\text { conservation }\end{array}$ & building's & 1.112 \\
$\begin{array}{l}\text { The function of heritage building's } \\
\text { conservation }\end{array}$ & 4.04 & 1.321 \\
$\begin{array}{l}\text { importance of heritage buildings' } \\
\text { conservation }\end{array}$ & 4.01 & 1.132 \\
$\begin{array}{l}\text { Method of heritage building's } \\
\text { conservation }\end{array}$ & 3.78 & 1.161 \\
Overall & 3.98 & 1.181 \\
\hline
\end{tabular}

This study showed that the community of George Town had an awareness of conservation matters for heritage buildings. If the local communities were to be given more exposure to the methods, functions, and importance of heritage building conservation at George Town, the community would be more concerned about the heritage buildings as a World Heritage Site.

\section{CONCLUSION}

In conclusion, the level of awareness among the local community of George Town towards the conservation of heritage buildings is at $\min =3.98$, which is a moderately good level though still requires improvement. Local communities should also be more actively involved in heritage building conservation activities to cultivate a sense of ownership towards their heritage. Thus, the existing cultural heritage could be passed on from one generation to another and ensure continuity. More effective initiatives should also be implemented to encourage local communities to engage in conservation activities. As heritage awareness is closely related to community involvement, stakeholders, especially NGOs, need 
Ummu Liyana \& Noordeyana

Awareness of Community on The Conservation of Heritage Buildings In George Town, Penang

to play their part by organising more conservation-related campaigns to increase awareness of local communities, especially owners and tenants of heritage premises. This research can help the owners and tenants of heritage premises understand the function and importance of heritage buildings that they were living in to appreciate the value and nurture the sense of patriotism.

\section{ACKNOWLEDGEMENT}

This work was supported by the Geran Kursi Endowment MPOB-UKM (EP2020-034)

\section{REFERENCES}

A Ghafar Ahmad. (2009). Celebrating Malaysia's World Heritage Sites: The Historic Cities of Melaka and George Town. ACCU Nara International Correspondent: The Second and the Third Regular Report. Cultural Heritage Protection Cooperation Office, Asia/Pacific Cultural Centre for UNESCO (ACCU), Nara, Jepun, 8-9.

A Ghafar Ahmad. (2010). Pemuliharaan Bangunan Warisan Di Malaysia Pengalaman Dan Cabaran Masa Hadapan. Universiti Sains Malaysia, Pulau Pinang. (In Malay)

Aisiah, A., Suhartono, S., \& Sumarno, S. (2016). The Measurement Model of Historical Awareness. Research and Evaluation in Education 2(2): 108-121.

Asyaari M. (2018). The Importance of The Conservation/Preservation Works: A Challenge Towards the Future of National Heritage. Planning Malaysia: Journal of the Malaysian Institute of Planners 16(4): 199-207.

Awad, J., Bleibleh, S. (2020). Preserving cultural heritage: Shifting paradigms in the face of war, occupation, and identity. Journal of Cultural Heritage. https://doi.org/10.1016/j.culher.2020.02.013.

Azmin, A. K., Kassim, M. H., Abdullah, F., \& Sanusi, A. N. Z. (2017). Architectural heritage restoration of Rumah Datuk Setia via mobile augmented reality restoration. Planning Malaysia 15(1): 139-50.

Balvin K. (2019). Form dept for heritage buildings. New Straits Times. https://www.nst.com.my/news/nation/2019/05/491679/form-deptheritagebuildings [retrieved on 27 May 2019].

Boudiaf, B. (2017). The impact of tourism on the revitalisation of the historical center. International Conference on Protecting Cultural Heritage of the Muslim World, IRCICA and ISESCO, 1st \& 2nd November 2017, Istanbul, Turkey.

Castro, F.M., Guccio, C., Rizzo, I. (2011). Public intervention on heritage conservation: a semi-parametric analysis of the determinants of regulation authorities' performance. International Tax and Public Finance 18(1): 1-16.

Esther H.K.Y., Lawrence W.C. Lai, Philip L.H. Yu. (2016). Public decision making for heritage conservation: A Hong Kong empirical study. Habitat International 53:312-319.

Hafsah FJ, Susilo N.A., Cokro D., Dedy Tri H., Wahdi April S.Y., Ferry Fadzlul R. (2019). Awareness and Knowledge Assessment of Sustainable Development Goals Among University Students. Jurnal Ekonomi \& Studi Pembangunan 20(2): $163-175$. 
Hamsah, E. (2006). Pemeliharaan kawasan warisan - Kajian kes zon pemuliharaan dan pemugaran. Bengkel konservasi monumen dan tapak tanah bersejarah. Hotel Mahkota, Melaka 27-29 November. (In Malay)

Hargreaves, A., \& Fink, D. (2004). The Seven Principles of Sustainable Leadership. Educational leadership, 61(7): 8-13.

Haroun, HAAF, Bakr, A.F., Hasan, A.E.S. (2019). Multi-criteria decision making for adaptive reuse of heritage buildings: Aziza Fahmy Palace, Alexandria, Egypt. Alexandria engineering journal 58: 467-478.

M. A. Azizan, N. Z. Noriman, H. Desa, N. Ishak, Omar S. Dahham, M. U. Umar, N. A. Lati. (2020). The Challenges in Conservation Practices in Malaysia: A Study in UNESCO Heritage Site, Georgetown, Penang, Malaysia. AIP Conference Proceedings 2213(1):1-4.

Mohd Jaki M. (2014). Penglibatan masyarakat dalam pemuliharaan kawasan warisan di pusat bandaraya Ipoh, Perak. Tesis Dr. Falsafah, Pusat Pengajian Perumahan, Bangunan dan Perancangan, Universiti Sains Malaysia. (In Malay)

Muhammad Yusri M. (2017). Tiga lagi bangunan warisan didakwa ditukar guna. BH Online. https://www.bharian.com.my/berita/nasional/2017/10/339421/tiga-lagibangunan-warisan-didakwa-ditukar-guna [retrieved on 19 October 2017]. (In Malay)

Nor Zalina H., Nur 'Adilah H., \& Noordeyana T. (2020). Nilai simbolik sebagai penunjuk kelestarian modal sosial petempatan tradisional di Kuala Terengganu, Malaysia. Malaysia Journal of Society and Space 16(3): 201-218. (In Malay)

Normah A. L., Norazmawati M. S., Syarmila Hany H., Rosniza H., Adaweia Nuur AB, Mohd Umzarulazijo U. (2018). Visitors' perspectives towards the conservation of heritage building: the case study of gurney paragon mall, Penang. Planning Malaysia: Journal of the Malaysian Institute of Planners 16(4): 143-154.

Nurbaidura S., \& Badaruddin M. (2018). The evolution of historic waterfront: A case study of George Town, Penang. Planning Malaysia: Journal of the Malaysian Institute of planners 16(4): 40-54.

S. Johar, A.G. Ahmad, A.I. Che-Ani, N.M. Tawil, I.M.S Usman. (2011). Analisa Kajian Lapangan ke atas Kecacatan Pada Bangunan Masjid Lama di Malaysia. Journal Design and Built: 44-62. (In Malay).

Sesana, E., Gagnonb, A.S. Bonazzac, A., Hughes, J.J. (2020). An integrated approach for assessing the vulnerability of World Heritage Sites to climate change impacts. Journal of cultural heritage 41: 211-224.

Solihah M, Mazdi M, Ruzanna Syamimi R, Jabil M, Mohamad Kadir ZA, Mohamad Pirdaus Y. (2015). Pengurusan bandar warisan UNESCO dan penglibatan komuniti tempatan: Kajian kes di George Town, Pulau Pinang. Malaysian Journal of Society and Space 11(12): 87 - 99. (In Malay).

Suraiyati R. (2018). Emerging Built Heritage Commodification of Boutique Hotels in World Heritage Site: Evidence from George Town, Penang, Malaysia. Planning Malaysia: Journal of the Malaysian Institute of Planners 16(4): 104-116.

Tunbridge, JE and Ashworth G.J. (1996). Dissonant heritage: the management of the past as a resource in conflict. Chichester: John Wiley \& Sons.

Waterton E., Watson, S. (2015). The palgrave handbook of contemporary heritage research. Palgrave MacMillan. 
Ummu Liyana \& Noordeyana

Awareness of Community on The Conservation of Heritage Buildings In George Town, Penang

Yung, E. H., \& Chan, E. H. (2011). Problem issues of public participation inbuilt heritage conservation: Two controversial cases in Hong Kong. Habitat International 35(3): 457-466.

Received: $20^{\text {th }}$ January 2021. Accepted: $20^{\text {th }}$ April 2021 